\title{
Helminth Parasite Communities of Two Scorpaena spp. (Scorpaenidae) From Reefs of Veracruz, Mexico
}

\author{
Jesús Montoya-Mendoza ${ }^{1}$, Sandra Edith Badillo-López ${ }^{1}$, Isabel Araceli Amaro-Espejo ${ }^{1}$, \\ María del Refugio Castañeda-Chávez ${ }^{1}$, Fabiola Lango-Reynoso ${ }^{1} \&$ Ignacio Herrera-Martínez $^{1}$ \\ ${ }^{1}$ Tecnológico Nacional de México, Instituto Tecnológico de Boca del Río, Veracruz, México \\ Correspondence: Jesús Montoya-Mendoza, Laboratorio de Investigación Acuícola Aplicada, Tecnológico \\ Nacional de México, Instituto Tecnológico de Boca del Río, Carretera Veracruz-Córdoba km 12, Boca del Río, \\ 94290, Veracruz, México. Tel: 52-229-690-5010. E-mail: jesusmontoya@itboca.edu.mx
}

Received: April 21, 2018

doi:10.5539/jas.v10n9p504
Accepted: June 21, $2018 \quad$ Online Published: August 15, 2018

URL: https://doi.org/10.5539/jas.v10n9p504

This work was funded by the Tecnológico Nacional de México, Dirección General de Educación Superior Tecnológica, México, Clave 5242.14-P.

\begin{abstract}
Scorpaena brasiliensis and S. plumieri are relevant fish species in reef systems, but little is known about their parasitic helminth communities and their structure. This paper describes such community in terms of species richness and diversity. A helminthological study was conducted on 33 specimens of S. brasiliensis and $36 S$. plumieri, captured in the Pajaros and Cabezo Reefs, in the Veracruz Reef System National Park (VRSNP), Veracruz, Mexico. The helminth community structure was analyzed in both host species. A total of 10 parasitic species was registered in $S$. brasiliensis (5 digeneans, 1 cestode, 3 nematodes, 1 acanthocephalan), while $S$. plumieri hosted 11 species (4 digeneans, 1 monogenean, 1 cestode, 4 nematodes, 1 acanthocephalan), with 8 common species. The species with the highest prevalence were Pseudocapillaria (Icthyocapillaria) sp., with $18.2 \%$ and $19.4 \%$ in S. brasiliensis and S. plumieri, respectively. Component community richness for $S$. brasiliensis was $S=10$, with Shannon index diversity value of $H^{\prime}=2.08$. For $S$. plumieri, such values were of $S$ $=11$ and $H^{\prime}=1.91$. Richness and diversity in the component and infracommunity levels for both hosts are lower than in other parasite communities of marine fishes in the southern Gulf of Mexico.
\end{abstract}

Keywords: richness, diversity, infracommunity, helminthes, parasites, Mexico

\section{Introduction}

Scorpenid fish are associated to rocky substrates and reef formations in the West Atlantic Ocean, and are distributed from the US to Brazil, including the Gulf of Mexico and the Caribbean Sea (Smith-Vaniz et al., 1999). Some species are popular due to sting injuries inflicted to unwary bathers (Field-Cortazares \& Calderon-Campos, 2010), but most species have no commercial relevance given their low capture volumes, i.e., S. plumieri (Haddad et al., 2003; Fuentes-Mata \& Espinoza-Pérez, 2010). Information related to parasitic helminths on these hosts is scarce (Cervigón et al., 1992). Available records include Helicometrina nimia in S. agassizii; H. nimia, Neopecoelus scorpaenae and Sterrhurus floridensis in S. brasiliensis; Derogenes varicus, Opecoelina scorpaenae and Pseudopecoelus vulgaris in S. cristulata; N. scorpaenae in S. grandicornis; Sterrhurus sp. in $S$. inermis; B. scorpaenae, H. nimia, S. floridensis in S. plumieri, all from Florida, USA (Manter, 1947); B. scorpaenae in $S$. plumieri from Louisiana, USA (Corkum, 1967); Lecithochirium parvum and L. microcercus in S. plumieri from Puerto Rico (Dyer et al., 1985); H. nimia in S. plumieri from Puerto Rico (Siddiqi \& Cable, 1960) and Brazil (Travassos et al., 1967; Roumbedakis et al., 2014); Pseudopecoelus scorpaenae in S. plumieri from Mexico (Pérez-Ponce de León et al., 2007). On the other hand, little is known about the community structure of helminth parasites in these hosts, as compared to other marine fish, such as carangids and lutjanids from the Southern Gulf of Mexico (Montoya-Mendoza et al., 2014, 2016, 2017a), or other commercially relevant species from the Caribbean region (Aguirre-Macedo et al., 2007). In this report we describe the helminth community of $S$. brasiliensis and $S$. plumieri, in terms of species richness and diversity. 


\section{Method}

\subsection{Sampling Procedures}

From March to November, 2014, 33 specimens of S. brasiliensis and 36 of S. plumieri were collected for helminthological examination. Fish were captured with spear and SCUBA diving at 5-10 m depth in Pajaros Reef $\left(19^{\circ} 18^{\prime} 33^{\prime \prime} \mathrm{N}, 96^{\circ} 08^{\prime} 33^{\prime \prime} \mathrm{W}\right)$ and Cabezo Reef $\left(19^{\circ} 03^{\prime} 07^{\prime \prime} \mathrm{N}, 95^{\circ} 52^{\prime} 05^{\prime \prime} \mathrm{W}\right)$, in the Veracruz Reef System National Park (VRSNP), state of Veracruz, Mexico. Fish specimens were kept in plastic containers with ice and transported to the lab for examination within 24 hours post-capture. Tissues and organs were reviewed using a stereomicroscope. The external examination included skin, scales, fins, gills, eyes, nostrils, mouth, and anus. Gills were removed and analyzed separately in Petri dishes with seawater. Internal examination included mesenteries, liver, kidney, and gonads. The whole digestive system was placed in Petri dishes with $0.75 \%$ saline for examination. Helminths were fixed with hot $4 \%$ formalin and preserved in $70 \%$ ethyl alcohol, according to Lamothe (1997). Monogeneans, digeneans, cestodes, and acanthocephalans were stained using Mayer's paracarmine and Gomori's triple stain, and then dehydrated in a graded alcohol series, cleared with clove oil, and mounted whole in Canada balsam. Nematodes were studied on temporary slides and cleared in glycerin, after which they were preserved in 70\% alcohol (Vidal-Martínez et al., 2001). Voucher specimens were deposited at the National Helminths Collection (Colección Nacional de Helmintos) (CNHE), Institute of Biology of the National Autonomous University, Mexico City. Prevalence (percentage of infected hosts) and mean intensity (mean number of parasites per infected fish), were calculated following Bush et al. (1997).

\subsection{Sample Size}

Helminth communities were analyzed at component community (all helminths in all individuals examined), and infracommunity (helminths in each single fish examined) levels (Holmes \& Price, 1986; Bush et al., 1997). Sampling adequacy for the component community was evaluated with a procedure similar to that of the helminth parasites community as L. campechanus and L. synagris (Montoya-Mendoza et al., 2014; 2016), using a randomized (100x) sample-based species accumulation curve computed in EstimateS (version 8.0 RK Colwell, http://viceroy.eeb.unconn.edu/estimates) (Moreno \& Halffter, 2001). To determine the component community, we examined the asymptotic richness based on the Clench's model equation (Soberón \& Llorente, 1993), as well as the final slope of the randomized species accumulation curve (Jiménez-Valverde \& Hortal, 2003). Clench's model is described by the following function:

$$
V 2=(a \times V 1) /[1+(b \times V 1)]
$$

where, $V 2$ is observed richness, $V 1$ is the number of hosts examined; $a$ and $b$ are curve parameters: $a$ equals the new species adding rate, and $b$ is a parameter related to the curve shape. These values were calculated iteratively using the EstimateS and Statistica (StatSoft, Inc., Tulsa, Oklahoma) software, as in Jiménez-Valverde and Hortal (2003). The slope of the cumulative species curve was calculated as $a /(1+b \times n)^{2}$, where $a$ and $b$ are parameters above, and $n$ is the number of hosts examined from a given component. Clench's model equation allows estimating the total number of species in a component as $a / b$. To determine the number of rare species missing at the component community level, the nonparametric species-richness estimator bootstrap was calculated from data observed, as recommended by Poulin (1998). The Shannon index of diversity $\left(H^{\prime}\right)$, was calculated for the component community as in Magurran (2004). Descriptors of infracommunity included the mean number of helminth species per fish, the mean number of helminth individuals per fish, and the mean value of the Brillouin's diversity index per fish $(H)$. Similarity among two parasite communities was estimated using the Jaccard similarity index (Magurran, 2004).

\section{Results}

We examined 33 specimens of Scorpaena brasiliensis (total length: 15-35 cm, mean: 27.06 \pm 4.63 ; weight: 120-1091 gr, mean 521.24 \pm 255.12 ); and $36 \mathrm{~S}$. plumieri (total length: $20-41.3 \mathrm{~cm}$, mean: $28.20 \pm 5.06$; weight: 207-1499 gr, mean: 553.25 \pm 312.23$)$. In both hosts, a total of 13 species of helminths were collected, 10 in $S$. brasiliensis: 5 digeneans (4 adults, 1 metacercaria), 1 cestode (larva), 3 nematodes ( 2 adults, 1 larva), and 1 acanthocephalan (juvenile). In S. plumieri, 11 species were found: 4 digeneans (3 adults, 1 metacercaria), 1 monogenean, 1 cestode (larva), 4 nematodes ( 2 adults, 2 larvae), and 1 acanthocephalan (juvenile). Both species shared 8 helminth species (Table 1).

The analysis of cumulative species curves for the component community suggested that the inventory of helminth species, when collecting $80 \%$ of the species, and the slope of the cumulative species curve for $S$. brasiliensis was 0.06 . Thus, an asymptote was reached, and richness estimated by the Clench's model was 12 species $(a=1.13, b=0.09 ; a / b=12.5)$. For $S$. plumieri, when collecting $84 \%$ of the species, such value was 0.06 , 
an asymptote was also reached, and richness estimated by the Clench's model was 13 species $(a=1.35, b=0.09$; $a / b=13.5)$. The value of the nonparametric species-richness estimator bootstrap ( $S$. brasiliensis, Sb $=9 ; S$. plumieri, $S b=13$ ) confirms that most, if not all, helminth species from the component community were recovered from both host species.

\subsection{Parasitic Parameters}

In general, parasitic parameters were low for all helminths found in both host species, with prevalence values $<$ 20\%; for example, Pseudocapillaria (Icthyocapillaria) sp., (18.2\%) in S. brasiliensis and (19.4\%) in S. plumieri. Mean intensity was $<5$ helminths per infected fish, with exception of Neopecoelus scorpaenae in S. plumieri (9.75). Five parasite species had only one specimen per host, as follows: S. brasiliensis: Didymozoidae gen. sp., and Gorgorhynchus sp.; S. plumieri: Benedenia sp., Bucephalus scorpaena, and Anisakis sp., these five species, together with Bucephalus scorpaena and Serrasentis sagittifer, made the difference in the species composition of parasite communities in both hosts (Table 1). No significant correlation was found between the total number of species $(S)$ or the total number of helminths $(N)$, with size and weight of $S$. brasiliensis [(total host length vs. $S$, r $=0.1$; vs. $N, \mathrm{r}=0.2$ ), (weight vs. $S, \mathrm{r}=0.2$; vs. $N, \mathrm{r}=0.2)$ ]; nor with $S$. plumieri [(total host length vs. $S, \mathrm{r}=0.3$; vs. $N, \mathrm{r}=0.3$ ), (weight vs. $S, \mathrm{r}=0.2$; vs. $N, \mathrm{r}=0.04)$ ]. However, a highly significant correlation $(\mathrm{r}=0.84)$ was found between prevalence and mean intensity of helminth species of $S$. brasiliensis, while no significant correlation was found in S. plumieri $(\mathrm{r}=0.53)$.

Table 1. Prevalence and mean intensity of parasitic helminths in scorpaenids from El Cabezo and Pájaros reefs, VRSNP, Veracruz, México

\begin{tabular}{|c|c|c|c|c|c|c|c|c|}
\hline \multirow{2}{*}{ Specie $^{+}$} & \multirow{2}{*}{ CNHE } & \multirow{2}{*}{ Site } & \multicolumn{3}{|c|}{ Scorpaena brasiliensis } & \multicolumn{3}{|c|}{ Scorpaena plumieri } \\
\hline & & & $\mathrm{n}(\% \mathrm{p})$ & $\mathrm{mi} \pm \mathrm{SD}$ & range & $\mathrm{n}(\% \mathrm{p})$ & $\mathrm{mi} \pm \mathrm{SD}$ & range \\
\hline \multicolumn{9}{|l|}{ Monogenea } \\
\hline Benedenia sp. & - & gill & & & & $1(2.77)^{*}$ & $1 \pm 0$ & 1 \\
\hline \multicolumn{9}{|l|}{ Digenea } \\
\hline Lecithochirium floridense & 10679,10686 & int & $5(15.1)$ & $2.4 \pm 1.3$ & $1-4$ & $4(11.1)$ & $2.3 \pm 0.5$ & $2-3$ \\
\hline Pseudopecoelus scorpaenae ${ }^{* *}$ & 10680,10687 & int & $6(18.2)$ & $1.8 \pm 1.3$ & $1-4$ & $4(11.1)$ & $9.8 \pm 7.9$ & $1-20$ \\
\hline Bucephalus scorpaenae $* *$ & 10681,10688 & int & $1(3)^{*}$ & $5 \pm 0$ & 5 & $1(2.77)$ & $1 \pm 0$ & 1 \\
\hline Derogenes sp. & 10682 & int & $1(3)^{*}$ & $3 \pm 0$ & 3 & & & \\
\hline Didymozoidae gen. sp. ${ }^{(m t)}$ & 10683,10689 & int & $1(3)^{*}$ & $1 \pm 0$ & 1 & $3(8.3)^{*}$ & $1.3 \pm 0.5$ & $1-2$ \\
\hline \multicolumn{9}{|l|}{ Cestoda } \\
\hline Tetraphyllidea gen. sp. ${ }^{(p)}$ & 10684,10694 & int & $4(12.1)^{*}$ & $3.5 \pm 3.1$ & $1-8$ & $9(25)^{*}$ & $1.7 \pm 1$ & $1-4$ \\
\hline \multicolumn{9}{|l|}{ Nematoda } \\
\hline Pseudocapillaria (Pseudocapillaria) sp. & 10696,10694 & int & $5(15.1)^{*}$ & $1.4 \pm 1$ & $1-3$ & $6(16.6)^{*}$ & $2.1 \pm 2$ & $1-6$ \\
\hline Pseudocapillaria (Icthyocapillaria) sp.** & 10697,10695 & int & $6(18.2)^{*}$ & $1.8 \pm 1.6$ & $1-5$ & $7(19.4)^{*}$ & $1.7 \pm 1.2$ & $1-4$ \\
\hline Anisakis sp. ${ }^{(l)}$ & 10692 & mes & & & & $1(2.8)^{*}$ & $1 \pm 0$ & 1 \\
\hline Contracaecum sp. ${ }^{(l)}$ & 10698,10693 & int & $3(9)^{*}$ & $2.6 \pm 2$ & $1-5$ & $4(11.1)^{*}$ & $2.3 \pm 2.5$ & $1-6$ \\
\hline \multicolumn{9}{|l|}{ Acanthocephala } \\
\hline Gorgorhynchus sp. & 10685 & mes & $1(3)^{*}$ & $1 \pm 0$ & 1 & & & \\
\hline Serrasentis sagittifer ${ }^{(j)}$ & 10691 & int & & & & $2(5.5)^{*}$ & $1.5 \pm 0.7$ & $1-2$ \\
\hline Total species & & & 10 & & & 11 & & \\
\hline
\end{tabular}

Note. ${ }^{+}$Specie. Life stages: $j$, juvenile; $l$, larva; $m t$, metacercarie; $p$, plerocercoid.

Abbreviations: int, intestine; mes, mesenteries; mi, mean intensity; n, number of infected hosts; \% p, prevalence; $\mathrm{SD}$, standard deviation; *, new host record; **, new record for Mexico.

\subsection{Component Community and Infracommunity}

A total of 181 helminths was collected in both host species. Out of these, 73 were found in S. brasiliensis. Infections ranged from 1 to 8 individuals per infected host. Richness of the component community was $S=10$, and the Shannon index diversity value was $H^{\prime}=2.08$. For the infracommunity in S. brasiliensis, 12 hosts were parasite-free $(36.3 \%)$, and richness ranged from 1 to 3 species of helminths per fish. Eleven hosts had a single helminth species; 8 hosts had 2, and 2 had 3. The average number of parasites species per individual host was $1.57 \pm 0.67$, while the average number of helminth individuals per host was $3.47 \pm 2.33$. The value of Brillouin's index for each infracommunity ranged from 0 to 0.76 with an average of $0.19 \pm 0.23$. The other 108 helminths 
were found in S. plumieri. Infections ranged from 1 to 20 individuals per infected host. Richness of the component community was $S=11$, and the Shannon index diversity value was $H^{\prime}=1.91$. The infracommunity for $S$. plumieri, 16 hosts were parasite-free (44.4\%), richness ranged from 1 to 6 species of helminths per fish. 10 hosts had 1 parasite species; 4 were infected by $2 ; 3$ had $3 ; 1$ had $4 ; 1$ had 5 ; and 1 had 6 . The average number of parasites species per individual host was $2.1 \pm 1.48$, while the average number of helminth individuals per host was 5.4 \pm 6.9 . The value of Brillouin's index for each infracommunity ranged from 0 to 1.15 with an average value of $0.31 \pm 0.38$. In the community components, we found a high similarity (Jaccard similarity index, $I J=$ 0.615), among the parasite communities of S. brasiliensis and S. plumieri, as they share eight species (Table 1).

\section{Discussion}

Adding the previous known parasites records for $S$. brasiliensis, which are: H. nimia, L. floridense, P. scorpaenae, S. musculus (Overstreet et al., 2009), and those reported in this investigation, the updated inventory of helminths for this host reached 12 helminth species. For S. plumieri, parasites known were: B. scorpaenae, H. nimia, L. floridense, P. scorpaenae, and S. musculus (Overstreet et al., 2009), and with those found in this work, the inventory of helminths for this host reached 13 helminth species. This investigation added 8 new host records for each host species, and 3 new locality records. In addition, both hosts share parasites with other scorpaenids, e.g., L. floridense in S. agassizii; B. scorpaenae and P. scorpaenae in S. grandicornis; and Derogenes sp. in S. maderensis (Overstreet et al., 2009). It has to be noted that they even share parasites records (L. floridense, metacercarie of Didymozoidae, larva of Tetraphyllidea, and Pseudocapillaria sp.), with the invasive scorpaenid Pterois volitans, the red lionfish, from the same locality (Montoya-Mendoza et al., 2017b). These observations showed that most adult parasites registered infest local scorpaenids, and that may be related to their distribution area, but now they can also be found in invasive scorpaenids, probably due to the transfaunal phenomenon displayed by larval forms.

On the other hand, our records of both parasite communities revealed that they are almost complete, but richness registered in both communities ( $S=10, S$. brasiliensis; $S=11, S$. plumieri), is considered low, when compared to other hosts in this area, for example, carangids (Caranx crysos, $S=21$; C. hippos, $S=18$; Trachinotus carolinus, $S=18$ ) (Montoya-Mendoza et al., 2017a), or lutjanids (Lutjanus campechanus, $S=21 ;$ L. synagris, $S=25$ ) (Montoya-Mendoza et al., 2014, 2016). Now, when these species richnesses and abundances are compared with parasite communities of local hosts such as Chloroscombrus chrysurus $(S=12)$, Oligoplites saurus $(S=7)$ (Montoya-Mendoza et al., 2017a), or others from the southeast of the Gulf of Mexico, i.e., Symphurus plagiusa $(S=8)$ (Rodríguez-González \& Vidal-Martínez, 2008), or the Caribbean Eugerres plumieri $(S=10)$ and Scomberomorus maculatus $(S=10)$ (Aguirre-Macedo et al., 2007), where they have not reached their maximum size (Aguirre-Macedo et al., 2007), samples are quite similar as related to the number of parasite species, therefore, they can be identified as communities with mean richness and abundance.

Low richness values of parasite species are usually associated with the host vagility, given that fish with high vagilities, such as C. crysos, C. hippos or L. campechanus, have higher species richness, and those with low vagility, like our hosts, have lower values. However, low richness in parasite communities of hosts studied here, could be associated to parasitic-host relationships, considering that richness and abundance records for parasite communities in scorpaenids from other latitudes have been low, as in S. guttata (Love \& Moser, 1983), S. notata, S. porcus and S. scrofa (Sasal et al., 1997; Öktener, 2014).

Another aspect that should be pointed out due to its effects on the parasite community richness, is the presence and distribution of intermediate hosts, and the definitive host itself, especially those who are a part of the host diet, based on prey such as penaeids, stomatopods, crabs, fish, and octopuses (Randall, 1967). They may be infected with larval stages of parasites, and considering that hosts have similar food sources, the similarity of $61.5 \%$ of the parasite species composition between both communities, could be explained (Deardoff \& Overstreet, 1981; Sasal et al., 1997; Aguirre-Macedo et al., 2007). On the other hand, the presence of parasite larvae suggests that both scorpaenid species are at an intermediate level in the marine food web, as smaller sizes are captured by predators, such as Dasyatis americana and some lutjanids (Randall, 1967).

Finally, data show that helminth communities of $S$. brasiliensis and S. plumieri have lower richness and diversity values than those found in other marine fish from the Southern Gulf of Mexico and the Caribbean (Randall, 1967; Sánchez-Ramírez \& Vidal-Martínez, 2002; Espínola-Novelo et al., 2013; Montoya-Mendoza et al., 2014, 2016, 2017a). The composition, richness, and diversity of helminth communities in S. brasiliensis and S. plumieri could be mainly associated to their distribution, intermediate and definitive hosts, feeding habits and low host vagility. 


\section{References}

Aguirre-Macedo, M. L., Vidal-Martínez, V. M., González-Solís, D., \& Caballero, P. I. (2007). Helminth communities of four commercially important fish species from Chetumal Bay, Mexico. Journal of Helminthology, 81, 19-31. https://doi.org/10.1017/S0022149X0721209X

Bush, A. O., Lafferty, K. D., Lotz, J. M., \& Shostak, A. W. (1997). Parasitology meets ecology on its own terms: Margolis et al. revisited. The Journal of Parasitology, 83, 75-83. https://doi.org/10.2307/3284227

Cervigón, F., Cipriani, R., Fischer, W., Garibaldi, L., Hendrickx, M., Lemus, A. J., ... Rodriquez, B. (1992). Fichas FAO de identificación de especies para los fines de la pesca. Guía de campo de las especies comerciales marinas y de aguas salobres de la costa septentrional de Sur América. FAO, Roma. Retrieved from http://www.fao.org/docrep/010/t0544s/t0544s00.htm

Corkum, K. C. (1967). Bucephalidae (Trematoda) in fishes of the Northern Gulf of Mexico: Bucephalus Baer, 1827. Transactions of the American Microscopical Society, 86, 44-49. https://doi.org/10.2307/3224423

Deardorff, T. L., \& Overstreet, M. (1981). Larval Hysterothylacium (= Thynnascaris) (Nematoda: Anisakidae) from fishes and invertebrates in the Gulf of Mexico. Proceedings of the Helminthological Society of Washington, 48, 113-26. Retrieved from http://bionames.org/bionames-archive/issn/0018-0130/48/113.pdf

Dyer, W. G., Williams, E. H., \& Bunkley-Williams, L. (1985). Digenetic trematodes of marine fishes of the Western and Southwestern coasts of Puerto Rico. Proceedings of the Helminthological Society of Washington, 52, 85-94. Retrieved from http://bionames.org/bionames-archive/issn/0018-0130/52/85.pdf

Espínola-Novelo, J. F., González-Salas, C., Guillén-Hernández, S., \& MacKenzie, K. L. (2013). Metazoan parasites of Mycteroperca bonaci (Epinephelidae) off the coast of Yucatan, Mexico, with a checklist of its parasites in the Gulf of Mexico and Caribbean region. Revista Mexicana de Biodiversidad, 84, 1111-1120. https://doi.org/10.7550/rmb.27989

Field-Cortazares, J., \& Calderón-Campos, R. (2010). Picadura por pez roca. Boletín Clínico Hospital Infantil del Estado de Sonora, 27, 83-86.

Fuentes-Mata, P., \& Espinoza-Pérez, H. (2010). Biodiversidad de los peces mexicanos y su aprovechamiento. Instituto de Biología, UNAM.

Haddad, Jr. V., Martins, I. A., \& Makyama, H. M. (2003). Injuries caused by scorpion fishes (Scorpaena plumieri Bloch, 1789 and Scorpaena brasiliensis Cuvier, 1829) in the Southwestern Atlantic Ocean (Brazilian coast): epidemiologic, clinic and therapeutic aspects of 23 stings in humans. Toxicon, 42, 79-83. https://doi.org/10.1016/S0041-0101(03)00103-X

Holmes, J. C., \& Price, P. W. (1986). Communities of Parasites. In D. J. Anderson, \& J. Kikkawa (Eds.), Community Ecology: Patterns and Processes (pp. 187-213). Blackwell Scientific Publications, Oxford, UK.

Jiménez-Valverde, A., \& Hortal, J. (2003). Las curvas de acumulación de especies y la necesidad de evaluar la calidad de los inventarios biológicos. Revista Ibérica de Aracnología, 8, 151-61.

Lamothe-Argumedo, R. (1997). Manual de técnicas para preparar y estudiar los parásitos de animales silvestres. RGT Editor, México.

Love, M. S., \& Moser, M. (1983). A checklist of parasites of California, Oregon, and Washington marine and estuarine fishes. U.S. Dep. Commer. NOAA Tech. Rep., NMFS SSRF 777.

Magurran, A. E. (2004). Measuring biological diversity. Blackwell Publishing, Oxford, UK.

Manter, H. W. (1947). The digenetic trematodes of marine fishes of Tortugas, Florida. The American Midland Naturalist, 38, 256-427. Retrieved from http://www.jstor.org/stable/2421571

Montoya-Mendoza, J., Camarena-Luhrs, T., Castañeda-Chávez, M. R., \& Lango-Reynoso, F. (2017b). Helminth parasites of red lionfish, Pterois volitans from the Veracruz coral reef system, Mexico, Southern Gulf of Mexico. Journal of Agricultural Science, 9, 30-33. https://doi.org/10.5539/jas.v9n11p30

Montoya-Mendoza, J., Castañeda-Chávez, M. R., Lango-Reynoso, F., \& Rojas-Castañeda, S. (2016). Helminth parasites of lane snapper, Lutjanus synagris from Santiaguillo reef, Veracruz, Mexico. Journal of Agricultural Science, 8, 81-8. https://doi.org/10.5539/jas.v8n11p81

Montoya-Mendoza, J., Jiménez-Badillo, L., Salgado-Maldonado, G., \& Mendoza-Franco, E. F. (2014). Helminth parasites of the red snapper, Lutjanus campechanus (Perciformes: Lutjanidae) from the reef Santiaguillo, Veracruz, Mexico. The Journal of Parasitology, 100, 868-72. https://doi.org/10.1645/13-429.1 
Montoya-Mendoza, J., Salgado-Maldonado, G., Favila-Castillo, M. E., Vázquez-Hurtado, G., \& CastañedaChávez, M. R. (2017a). Communities of helminth parasites in five Carangidae species from the coast of Veracruz, Mexico, Southern Gulf of Mexico. The Global Journal of Science Frontier Research, 17, 7-18. Retrieved from https://journalofscience.org/index.php/GJSFR/article/view/1976/1837

Moreno, C. E., \& Halffter, G. (2001). On the measure of sampling effort used in species accumulation curves. Journal of Applied Ecology, 38, 487-90. https://doi.org/10.1046/j.1365-2664.2001.00590.x

Öktener, A. (2014). An updated checklist of parasitic helminths of marine fish from Turkey. Transylvanian Review of Systematical and Ecological Research, 16, 55-96. https://doi.org/10.1515/trser-2015-0017

Overstreet, R. M., Cook, J. O., \& Heard, R. (2009). Trematoda (Platyhelminthes) of the Gulf of Mexico. In D. W. Felder, \& D. K. Camp (Eds.), Gulf of Mexico-Origins, Waters, and Biota (Volume 1), Biodiversity (pp. 419-486). Texas A\&M University Press, College Station, Texas, USA.

Pérez-Ponce de León, G., García-Prieto, L., \& Mendoza-Garfias, B. (2007). Trematode parasites (Platyhelminthes) of wildlife vertebrates in Mexico. Zootaxa, 1534, 1-247. Retrieved from http://www.mapress.com/zootaxa/2007f/z01534p247f.pdf

Poulin, R. (1998). Comparison of three estimators of species richness in parasite component communities. The Journal of Parasitology, 84, 485-90. Retrieved from http://www.jstor.org/stable/3284710

Randall, J. E. (1967). Food habits of reef fishes of the West Indies. Front Cover. University of Miami, Institute of Marine Science, Nature.

Rodríguez-González, A., \& Vidal-Martínez, V. M. (2008). Las comunidades de helmintos del lenguado (Symphurus plagiusa) en la costa de Campeche, México. Revista Mexicana de Biodiversidad, 79, 159-173. Retrieved from file://C:/Users/usuario/Downloads/525-644-1-PB.pdf

Roumbedakis, K., Marchiori, N. C., Garcia, P., Pereira-Junior, J., Castro, L. A. S., \& Martins, M. L. (2014). Helicometrina nimia Linton, 1910 (Digenea: Opecoelidae) in dusky grouper Epinephelus marginatus (Lowe, 1834) (Teleostei: Serranidae) from southeastern Brazil. Brazilian Journal of Biology, 74, 472-479. https://doi.org/10.1590/1519-6984.12612

Sánchez-Ramírez, C., \& Vidal-Martínez, V. M. (2002). Metazoan parasite infracommunities of Florida pampano (Trachinotus carolinus) from the coast of the Yucatan Peninsula, Mexico. The Journal of Parasitology, 88, 1087-1094. https://doi.org/10.1645/0022-3395(2002)088[1087:MPIOFP]2.0.CO;2

Sasal, P., Morand, S., \& Guegan, J.-F. (1997). Determinants of parasite species richness in Mediterranean marine fishes. Marine Ecology Progress Series, 149, 61-71. https://doi.org/10.3354/meps149061

Siddiqi, A., \& Cable, R. (1960). Digenetic trematodes of marine fishes of Puerto Rico. Scientific Survey of Porto Rico and Virgin Islands, 17, 260-325.

Smith-Vaniz, W. F., Collette, B. B., \& Luckhurst, B. E. (1999). Fishes of Bermuda: History, zoogeography, annotated checklist, and identification keys. American Society of Ichthyologists and Herpetologists.

Soberón, M. J., \& Llorente, J. (1993). The use of species accumulation functions for the prediction of species richness. Conservation Biology, 7, 480-88. https://doi.org/10.1046/j.1523-1739.1993.07030480.x

Travassos, L., Freitas, J. F. T., \& Bührnheim, P. F. (1967). Relatório da excursão do Instituto Oswaldo Cruz ao estado do Espírito Santo em novembro de 1964. Boletim do Museu de Biologia Prof. Mello Leitão. Zoologia, 31, 1-5. Retrieved from http://nossacasa.net/BMBML/pdf/zo_031.pdf

Vidal-Martínez, V. M., Aguirre-Macedo, M. L., Scholz, T., Gonzalez-Solis, D., \& Mendoza-Franco, E. F. (2001). Atlas of the helminth parasites of cichlid fish of Mexico. Academia, Praha, Czech Republic.

\section{Copyrights}

Copyright for this article is retained by the author (s), with first publication rights granted to the journal.

This is an open-access article distributed under the terms and conditions of the Creative Commons Attribution license (http://creativecommons.org/licenses/by/4.0/). 